\title{
THE EFFICACY OF LOW-LEVEL LASER THERAPY IN BURNING MOUTH SYNDROME - A PILOT STUDY
}

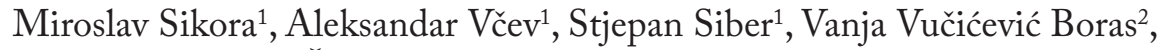 \\ Željko Rotim ${ }^{3}$ and Marko Matijević ${ }^{1}$
}

\author{
${ }^{1}$ School of Medicine, Josip Juraj Strossmayer University of Osijek, Osijek, Croatia; \\ ${ }^{2}$ Department of Oral Medicine, School of Dental Medicine, University of Zagreb, Zagreb, Croatia; \\ ${ }^{3}$ Department of Endodontics and Restorative Dentistry, School of Dental Medicine, \\ University of Zagreb Zagreb, Croatia
}

\begin{abstract}
SUMMARY - The aim of this clinical study was to compare low-level laser therapy (LLLT) switched on and switched off in the treatment of burning mouth syndrome (BMS). BMS is a debilitating condition for patients and highly demanding for physicians, characterized by burning symptoms in the oral cavity. Despite extensive research, so far only cognitive behavioral therapy and clonazepam have been proven successful for its treatment in randomized controlled trials. Forty-four patients with BMS were randomly assigned to the study laser group (LLLT) or the sham laser group. LLLT was performed with the GaAlAs laser $(830 \mathrm{~nm})$ used in non-contact mode on the site in the mouth where burning symptoms were present; study patients received 10 sessions (10 days). Each participant filled out the visual analog scale (VAS) and oral health impact on the quality of life scale (OHIP-CRO 14) before and after either therapy protocol. There were no significant differences between the groups before and after LLLT (switched on and off) in the quality of life (OHIP CRO 14 scores) ( $p>0.05)$. There was significant decrease in pain symptoms (VAS) in both LLLT switched on and LLLT switched off groups ( $p<0.05)$. Both LLLT switched on and switched off decreased pain symptoms (VAS) in patients with BMS; however, neither LLLT switched off or switched on improved the OHIP-CRO 14 scores.
\end{abstract}

Key words: Low-Level Light Therapy; Burning Mouth Syndrome; Cognitive Therapy; Quality of Life

\section{Introduction}

Burning mouth syndrome (BMS) is a chronic pain syndrome characterized by burning symptoms in the oral cavity and with clinically healthy appearance of the oral mucosa, affecting mostly postmenopausal women ${ }^{1}$. Despite many studies, its etiopathogenesis has not been elucidated completely, albeit disturbances in peripheral and/or central nerve pathways have been suggested ${ }^{2}$. Many of the recommended therapies have not been successful except for topical clonazepam and

Correspondence to: Vanja Vuciciević Boras, DMD, PhD, Department of Oral Medicine, School of Dental Medicine, University of $\mathrm{Za}^{-}$ greb, Gundulićeva 5, HR-10000 Zagreb, Croatia

E-mail: boras@sfzg.hr

Received December 15, 2016, accepted January 15, 2017 cognitive behavioral therapy ${ }^{3}$. Miziara et al. ${ }^{4}$ stated that so far only topical clonazepam, alpha-lipoic acid and cognitive behavioral therapy have proven successful in randomized controlled trials. Furthermore, Cui et al..$^{5}$ searched PubMed, MEDLINE, EMBASE, Web of Science (TS) and Cochrane Library and found three randomized controlled trials (RCTs) and two high-quality case-control studies involving 195 BMS patients, which reveal that clonazepam can reduce oral pain symptoms in patients with BMS. Klasser et al. ${ }^{6}$ also state that there is an urgent need for further investigations to determine the efficacy of different therapies as to determine appropriate therapeutic options for BMS sufferers. Beneng and Renton ${ }^{2}$ concluded that, while there is no cure for BMS symptoms, BMS patients take various neuropathic pain medication, 
salivary substitutes and other non-medical interventions that help the patient "get through the day".

In the published literature on PubMed there are only ten studies on the use of low-level laser therapy (LLLT) in BMS patients. According to our knowledge, there have been only three studies published so far on the placebo effect of LLLT (i.e. when LLLT was switched off $)^{7-9}$. Therefore, the aim of this study was to compare switched on and switched off (sham) LLLT in the treatment of BMS.

\section{Materials and Methods}

\section{Patient selection}

This randomized clinical single-blinded study was performed in the Osijek Health Centre from September 2015 until June 2016. The study was approved by the Ethics Committee of the School of Medicine in Osijek, Croatia. Standards of the Helsinki Declaration were followed ${ }^{10}$. All selected patients signed an informed consent before undergoing the research procedure, agreeing to their participation in the study.

The study sample consisted of 44 participants (one male and 43 females; age range 56-83, mean age 67.56 years), randomly selected from the group of patients presenting to dental office because of the burning mouth symptoms. The diagnosis of primary BMS was established as follows: burning sensation in the otherwise clinically normal oral mucosa and absence of local and systemic factors that can lead to burning sensation of the oral mucosa. Local and systemic factors were eliminated by salivary flow rate test, complete blood count, serum iron, vitamin B12, folic acid, thyroid hormones, and blood glucose. The exclusion criteria were inability to comprehend the text of the informed consent form and inability to comprehend the questionnaire.

\section{Low-level laser therapy procedure (LLLT)}

Prior to and after either therapy, participants filled out the visual analog scale (VAS) and Oral Health Impact Profile questionnaire, Croatian version (OHIP-CRO 14 $)^{11}$. By simple method of flipping the coin, participants were allocated in two groups: LLLT switched on and LLLT switched off (control group, sham laser group). The participants did not know which group they were assigned to (single-blinded study).
The LLLT was performed by the Gallium-Aluminum-Arsenide (GaAlAs) laser (BTL, Prague, Czech Republic) with wavelength of $830 \mathrm{~nm}$. Laser parameters were set at: average power of $100 \mathrm{~mW}$, chopped mode (switched on: $800 \mathrm{~ms}$, switched off: $1 \mathrm{~ms}$ ), fluence: $12 \mathrm{~J} /$ $\mathrm{cm}^{2}$, duty factor of $80 \%$, area: $1 \mathrm{~cm}^{2}$. Laser irradiation was applied in non-contact mode on the site in the mouth where burning symptoms were present. The distance between the probe and the irradiated area was kept constant at approximately $5 \mathrm{~mm}$ throughout the treatment protocol. The slow circulation movements were performed during the treatment. The LLLT was repeated every day except for weekend for 14 days (10 sessions). Every session lasted for 5 minutes.

Each participant filled out the VAS and OHIPCRO 14 before and after either therapy ${ }^{11}$.

\section{Statistical analysis}

Normality of distribution was assessed by Kolmogorov-Smirnov test. Due to normal distribution of the variables, parametric statistics was used. Data were expressed as mean \pm standard deviation. Differences between the groups were assessed by Student's t-test. Difference before and after treatment in each group was assessed by paired samples $t$ test. The values of $p$ lower than $0.05(\mathrm{p}<0.05)$ were considered statistically significant.

\section{Results}

Two participants did not fill out the VAS scale. There were no significant differences in either study or control group before and after LLLT (switched on and off) regarding the quality of life (OHIP CRO 14 scores) (Table 1$)$.

Significant difference before and after laser on and off regarding VAS scores (decrease of pain symptoms)

Table 1. OHIP scores before and after therapy protocol in study ('laser on') group and control ('laser off') group

\begin{tabular}{|l|l|l|l|}
\hline & Mean & SD & $\mathrm{p}$ \\
\hline $\begin{array}{l}\text { OHIP before and after } \\
\text { in 'laser on' group } \\
\begin{array}{l}\text { OHIP before and after } \\
\text { in 'laser off' group }\end{array}\end{array}$ & 2.727 & 8.631 & 0.153 \\
\hline
\end{tabular}

OHIP = Oral Health Impact Profile questionnaire; SD = standard deviation; $p=$ statistical significance set at 0.05 
Table 2.VAS scores before and after therapy protocol in study ('laser on') group and control ('laser off') group

\begin{tabular}{|l|l|l|l|}
\hline & Mean & SD & $\mathrm{p}$ \\
\hline $\begin{array}{l}\text { VAS before and after } \\
\text { in 'laser on' group } \\
\begin{array}{l}\text { VAS before and after } \\
\text { in 'laser off' group }\end{array}\end{array}$ & 1.458 & 2.322 & 0.005 \\
\hline
\end{tabular}

VAS = visual analog scale; $\mathrm{SD}$ = standard deviation; $\mathrm{p}$ = statistical significance set at 0.05

was found in both study group ('laser on') and control group ('laser off') (Table 2).

\section{Discussion}

There are only three studies published so far on the placebo effect of LLLT (i.e. when LLLT was switched off $)^{7-9}$. Arbabi-Kalati et al. ${ }^{7}$ compared LLLT on and LLLT off (sham) in 20 patients with BMS. The LLLT was performed with $630 \mathrm{~nm}$ diode laser (power 30 $\mathrm{mW}$ ) for 10 seconds twice a week. After four weeks of treatment, LLLT reduced burning sensation and improved the quality of life. Furthermore, Spanemberg et $a l .^{9}$ also report decreased symptoms and improved quality of life in $78 \mathrm{BMS}$ patients after eight weeks of LLLT at fluence of $176 \mathrm{~J} / \mathrm{cm}^{2}$ and $72 \mathrm{~J} / \mathrm{cm}^{2}$. In the present single-blinded study, LLLT $\left(12 \mathrm{~J} / \mathrm{cm}^{2}\right)$ decreased the burning mouth symptoms after 10 sessions. However, there was no improvement in the quality of life. Another interesting finding of this study was a decrease of symptoms in the placebo group where LLLT was off. It may be that placebo played an important role in alleviating burning symptoms in the patients included in the study.

In the study by Arduino et al. ${ }^{12}, 18$ patients with BMS were treated with LLLT using continuous mode of 980-nm AlGaAs laser (output power: $300 \mathrm{~mW}$, fluence: $10 \mathrm{~J} / \mathrm{cm}^{2}$ ) and the 'spot technique', with an average power density of about $1 \mathrm{~W} / \mathrm{cm}^{2}$ and the laser probe held perpendicularly at a distance of about $2 \mathrm{~mm}$ from the mucosa. The treatment lasted for five weeks with two laser irradiation sessions weekly. Finally, they concluded that LLLT was superior to clonazepam regarding improvement in pain perception at 8 weeks, based on the VAS, McGill Pain Questionnaire, present pain intensity and OHIP-49. The patients experienced reduction of burning symptoms from the end of first applications. However, LLLT did not influence anxiety and depression. Kato et al. ${ }^{13}$ irradiated 11 patients with BMS once a week for three consecutive weeks with an infrared laser $(790 \mathrm{~nm}$, fluence: $6 \mathrm{~J} / \mathrm{cm}^{2}$, output power: $120 \mathrm{~mW}$ ). The probe was kept in contact with the tissue. Burning symptoms were significantly lower after the end of LLLT. Patients reported an $80.4 \%$ reduction in the intensity of symptoms after LLLT. Dos Santos et al. ${ }^{14}$ investigated the effect of one weekly session of LLLT $(660 \mathrm{~nm}$, power: $40 \mathrm{~mW}$, fluence: $20 \mathrm{~J} / \mathrm{cm}^{2}$ ) for 10 weeks in ten patients with oral burning. All patients reported improvement in all sessions, with reduction in VAS scores by up to $58 \%$ after the $10^{\text {th }}$ session. Yang and Huang ${ }^{15}$ treated 17 BMS patients with an 800-nm wavelength diode laser $\left(1.5 \mathrm{~W} / \mathrm{cm}^{2}\right)$ between one and seven times. The results showed the mean reduction in pain by 47.6\% (ranging from 9.3\% to 91.8\%). The burning sensation remained unchanged for up to 12 months.

Romeo et al. ${ }^{16}$ report on beneficial effects of LLLT in 25 patients. All patients were irradiated with a double diode laser (fluence: $0.53 \mathrm{~J} / \mathrm{cm}^{2}$ ) for 15 minutes twice a week for 4 weeks. Seventeen (68\%) patients had relevant benefits while in 8 cases differences in burning were not relevant. Pezelj Ribaric et al. ${ }^{17}$ could not confirm significant difference in VAS after 4 weeks of LLLT, however, the salivary levels of tumor necrosis factor $\alpha$ and interleukin- 6 decreased significantly.

According to the above mentioned clinical studies, there still are differences in laser parameters and duration of LLLT among studies, thus direct comparison is not possible. Following the results of this study, it cannot be explained why the quality of life was not improved after LLLT, although VAS scores were improved in both the treatment and placebo groups. Therefore, more randomized single-blinded clinical studies comparing LLLT on and off (placebo) are necessary to clarify the role of LLLT in the treatment of patients with BMS.

In conclusion, both the switched on and switched off LLLT decreased pain symptoms in patients with BMS, however, neither of the therapy protocols improved the quality of life scores.

\section{References}

1. Buljan D, Savić I, Karlović D. Correlation between anxiety, depression and burning mouth syndrome. Acta Clin Croat. 2008; 47(4):211-6. 
2. Beneng K, Renton T. Pain Part 8: Burning mouth syndrome. Dent Update. 2016;43:254-6.

DOI: $10.12968 /$ denu.2016.43.3.254

3. Buchanan JA, Zakrzewska JM. Burning mouth syndrome. BMJ Clin Evid. 2010 Jul 19;2010.

4. Miziara I, Chagury A, Vargas C, Freitas L, Mahmoud A. Therapeutic options in idiopathic burning mouth syndrome: literature review. Int Arch Otorhinolaryngol. 2015;19:86-9.

5. Cui Y, Xu H, Chen FM, et al. Efficacy evaluation of clonazepam for symptom remission in burning mouth syndrome: a meta-analysis. Oral Dis. 2016;22:503-11.

DOI: 10.1111/odi.12422

6. Klasser GD, Grushka M, Su N. Burning mouth syndrome. Oral Maxillofac Surg Clin North Am. 2016;28:381-96. DOI: 10.1016/j.coms.2016.03.005

7. Arbabi-Kalati F, Bakhshani NM, Rasti M. Evaluation of the efficacy of low-level laser in improving the symptoms of burning mouth syndrome. J Clin Exp Dent. 2015;7:e524-7. DOI: 10.4317/jced.52298

8. Vukoja D, Alajbeg I, Vučićević Boras V, Brailo V, Alajbeg IZ, Andabak Rogulj A. Is effect of low-level laser therapy in patients with burning mouth syndrome result of a placebo? Photomed Laser Surg. 2011;29:647-8.

9. Spanemberg JC, López López J, de Figueiredo MA, Cherubini K, Salum FG. Efficacy of low-level laser therapy for the treatment of burning mouth syndrome: a randomized, controlled trial. J Biomed Opt. 2015;20:098001.

10. World Medical Association Declaration of Helsinki. Ethical principles for medical research involving human subjects. J Postgrad Med. 2002;48:206-8.
11. Petričević N, Čelebić A, Papić M, Rener-Sitar K. Croatian version of the Oral Health Impact Profile questionnaire. Coll Antropol. 2009;33:841-7.

12. Arduino PG, Cafaro A, Garrone M, Gambino A, Cabras M, Romagnoli E, Broccoletti R. A randomized pilot study to assess the safety and the value of low-level laser therapy versus clonazepam in patients with burning mouth syndrome. Lasers Med Sci. 2016;31:811-6.

13. Kato IT, Pellegrini VD, Prates RA, Ribeiro MS, Wetter NU, Sugaya NN. Low-level laser therapy in burning mouth syndrome patients: a pilot study. Photomed Laser Surg. 2010; 28:835-9.

14. dos Santos Lde F, Carvalho Ade A, Leão JC, Cruz Perez DE, Castro JF. Effect of low-level laser therapy in the treatment of burning mouth syndrome: a case series. Photomed Laser Surg. 2011;29:793-6.

15. Yang HW, Huang YF. Treatment of burning mouth syndrome with a low-level energy diode laser. Photomed Laser Surg. 2011;29:123-5. DOI: 10.1089/pho.2010.2787. Epub 2010 Oct 22.

16. Romeo U, Del Vecchio A, Capocci M, Maggiore C, Ripari M. The low-level laser therapy in the management of neurological burning mouth syndrome. A pilot study. Ann Stomatol. 2010;1:14-8.

17. Pezelj-Ribarić S, Kqiku L, Brumini G, et al. Proinflammatory cytokine levels in saliva in patients with burning mouth syndrome before and after treatment with low-level laser therapy. Laser Med Sci. 2013;28:297-301.

\title{
UČINKOVITOST LIJEČENJA NISKOENERGETSKIM LASEROM U SINDROMU PEKUĆIH USTA - PROBNO ISTRAŽIVANJE
}

\author{
M. Sikora, A. Včer, S. Siber, V. Vučicervić Boras, Ž. Rotim i M. Matijević
}

Cilj ovoga istraživanja je bio usporediti učinkovitost niskoenergetskog lasera koji je bio uključen i isključen u bolesnika sa sindromom pekućih usta (SPU). SPU je stanje koje iscrpljuje bolesnike, zahtjevno je za liječenje, a očituje se simptomima žarenja u usnoj šupljini. Usprkos brojnim istraživanjima do sada su se kognitivna bihejvioralna terapija i klonazepam jedini pokazali kao uspješan način liječenja SPU u randomiziranim kontroliranim istraživanjima. Četrdeset i četiri bolesnika s SPU su podijeljeni u skupinu koja je liječena upaljenim laserom i u skupinu koja je liječena ugašenim laserom. Liječenje laserom je provedeno uz pomoć lasera GaAlAs $(830 \mathrm{~nm})$ koji je korišten u nekontaktnom načinu rada na mjestu gdje su u ustima bili prisutni simptomi žarenja, a sudionici su dobili po deset terapija (deset dana). Svaki sudionik je prije i poslije istraživanja odredio stupanj boli na vizualnoj analognoj ljestvici (VAS) te ispunio upitnik o utjecaju oralnog zdravlja na kvalitetu života (OHIP-CRO 14). Nije bilo značajnih razlika između skupina prije i nakon liječenja laserom (upaljen i ugašen) u utjecaju oralnog zdravlja na kvalitetu života (OHIP CRO 14) (p>0,05). Utvrđeno je značajno smanjenje simptoma boli (VAS) u objema skupinama liječenim laserom (upaljen i ugašen) ( $\mathrm{p}<0,05)$. Upaljen i ugašen laser je doveo do smanjenja simptoma boli u bolesnika s SPU, doduše, niti jedan način liječenja laserom (upaljen ili ugašen) nije doveo do poboljšanja rezultata utjecaja oralnog zdravlja na kvalitetu života.

Ključne riječi: niskorazinska laserska terapija; sindrom pekucib usta; kognitivna terapija; kvaliteta života 